\title{
Identifikasi Jenis Cendawan pada Kelelawar (Ordo Chiroptera) di Kota Tangerang Selatan
}

\section{Identification of Fungi Species on Bats (Order Chiroptera) in South Tangerang City}

\author{
Fathoni $\mathrm{R}^{1}$, Radiastuti $\mathrm{N}^{2}$, Wijayanti $\mathrm{F}^{3}$ \\ ${ }^{123}$ Program Studi Biologi Fakultas Sains dan Teknologi, Universitas Islam Negeri (UIN) Syarif Hidayatullah \\ Jakarta, Indonesia.
}

Fathoni R, Radiastuti N, Wijayanti F. 2017 - Identifikasi Jenis Cendawan pada Kelelawar (Ordo Chiroptera) di Kota Tangerang Selatan. Jurnal Mikologi Indonesia 1(1), 28-37.

\begin{abstract}
Abstrak
Kelelawar merupakan salah satu spesies mamalia yang memiliki habitat cukup berdekatan dengan aktivitas manusia dan mampu terbang dalam jarak jauh. Habitat kelelawar dengan kondisi lembab, suhu rendah dan intensitas cahaya rendah berpotensi sebagai distribusi mikroba dan menyebabkan penyakit yang disebabkan oleh cendawan dan khamir yang ditemukan di kelelawar. Penelitian ini bertujuan untuk mengetahui jenis cendawan pada habitat kelelawar. Metode tangkapan menggunakan kelelawar untuk ditangkap dan dilepaskan dengan mist net dan sampel diambil secarapurposive sampling. Sampel yang dikumpulkan adalah rambut hidung dan air liur di mulut kelelawar. Hasil penelitian menunjukkan bahwa 4 jenis cendawan dan 2 spesies khamir diidentifikasi seperti Aspergillus niger, A. fumigatus, Fusarium sp., Mucor sp., Candida sp. dan Rhodotorula sp. Cendawan dan khamir yang ditemukan di kelelawar belum diketahu efek negatif terhadap kesehatan, namun beberapa genera cendawan memiliki patogen potensial pada organisme hidup lainnya
\end{abstract}

Kata kunci - Kelelawar - Fungi- Patogen- Khamir

\begin{abstract}
The bats are one species of the mammals that have sufficient habitat adjacent to human activity andable to fly in long distance. The habitat of bat with the damp conditions, low temperature and low light intensity could potentially lead to disease caused by fungi and yeasts found in the bats. This research aimed to identify the kind of fungus onthe bat habitat.The method catch of the bat use to catch and release method with mist netand conducted by the purposive sampling. The samples collectedwere the nose hair and saliva at the mouth of the bat.The results showedthat 4species of the fungus and 2 species of the yeasts were identified such asAspergillus niger, A. fumigatus, Fusarium sp., Mucor sp., Candida sp. and Rhodotorula sp.. It is unknown of serious detrimental health effects by fungi and yeast that found in the bats, but several genera of fungi have the potential pathogens in another living organism.
\end{abstract}

Keywords - Bats - Fungi-Pathogen- Yeast.

Dikirimkan 5 Januari 2016, Diterima 10 Februari 2017, Terbit online 20 Juni 2017

Corresponding Author: Nani Radiastuti - e-mail -n_radiastuti@yahoo.com 


\section{Pendahuluan}

Kelelawar merupakan hewan dari kelas Mamalia yang memiliki kemampuan adaptasi untuk terbang (Yin et al, 2011). Kelelawar termasuk dalam Ordo Chiroptera yang terdiri dari dua subordo yaitu Megachiroptera (kelelawar pemakan buah) dan Microchiroptera (kelelawar pemakan serangga) (Suyanto, 1998). Kelelawar merupakan salah satu jenis mamalia yang dikenal luas oleh masyarakat Indonesia karena satwa liar ini dimanfaatkan dagingnya sebagai obat di beberapa tempat di Indonesia. Walaupun kelelawar biasa dimanfaatkan oleh sebagian kecil masyarakat, namun sebagian besar masyarakat masih beranggapan bahwa kelelawar adalah hewan pemakan buah-buahan yang merugikan (Prasetyo et al, 2011). Kelelawar yang ada di Indonesia diperkirakan mencapai 230 spesies atau $21 \%$ dari spesies kelelawar yang ada di dunia. Spesies tersebut diantaranya 77 spesies dikelompokkan ke dalam sub ordo Megachiropteradan 153 spesies dikelompokkan ke dalam sub ordo Microchiroptera (Suyanto, 2001).

Setiap jenis kelelawar mempunyai beberapa pilihanlokasi sarang, diantaranya adalah pohon yang tinggi, di balik batu, di atap rumah, dan di dalam gua. Lingkungan tempat hidup kelelawar biasanya lembap, suhu yang rendah dan memiliki intensitas cahaya yang kurang. Hal tersebut berpotensi lingkungan yang cocok untuk pertumbuhan fungi.Salah satunya adalah cendawan yang berpotensi penyebab penyakitoleh cendawan yang hidup berasosiasi dengan kelelawar. Permasalahan yang utama adalah habitat hidup kelelawar berdekatan dengan manusia. Kelelawar merupakan salah satu hewan liar yang habitatnyacukup umum ditemui diantara manusia. kelelawar kadang beristirahat di bangunanserta tidak jarang memasuki perkebunan-perkebunan warga untuk mencari sumber pakan (Suryaman 2015). Menurut Hussein et al. (2011) hewanmemiliki potensi dalam epidemiologi penyakit pada manusia karena dapat menjadi vektor atau menciptakan lingkungan yang optimal bagicendawan patogen untuk tumbuh.Kelelawarmempunyai kemampuan sebagai reservoir dimana dapat terinfeksi suatu agen infeksius dan tidak menunjukkan gejala klinis pada dirinya. Agen infeksius yang menyerang biasanya berbahaya pada kesehatan manusia/zoonosis (Omatsu et al. 2007).

Menurut Institutional Animal Care and Use Committee (IACUC) (2008) kelelawar (Ordo Chiroptera) adalah reservoir bagi banyak agen infeksi, termasuk parasit, bakteri, virus, dan cendawan. Histoplasmosis, Kriptokokosis dan Blastomycosis adalah infeksi jamur yang kadang-kadang menginfeksi kelelawar dan dapat hadir dalam guano kelelawar. Penelitian Suryaman (2015) mengenai mikosis pada kelelawar ditemukan 6 dari 10 kelelawar diduga terinfeksiBlastomycosis. Seluruh kelelawar buah tersebut berasal dari satu koloni yang samasehingga hampir semuanyaterinfeksi oleh Blastomyces sp. Penelitian Saphiro et al. (2015) di Brazil berhasil mengisolasi cendawan yang berasosiasi dengan rambut bagian hidung pada kelelawar jenis Cynomops planirostris, Molossus molossus, dan Molossus rufus. Hasil dari riset tersebut didapatkan 11 jenis cendawan yang berasal dari genus Aspergillus, Cladosporium, Paecilomyces, danPenicillium. Beberapa jenis cendawan yang didapatkan tersebut diketahui bersifat patogen pada makhluk hidup lain.

Ada beberapa jenis cendawan dan khamir yang diduga menjadikan tubuh kelelawar di Kota Tangerang Selatan menjadi tempat hidupnya dan dimungkinkan cendawan tersebut bersifat patogen. Cendawan dan khamir patogen tersebut dapat menyebabkan masalah kesehatan bagi manusia karena secara tidak langsung kelelawar di perkotaan hidupnya juga bersinggungan dengan manusia.Alasantersebut yang mendasari dilaksanakannya penelitian ini. Dengan demikian diharapkan hasil penelitian ini dapat menjadi sumber informasi bagi masyarakat dan para peneliti kelelawar bahwa kelelawar dapat berpotensi menyebarkan penyakit yang disebabkan oleh cendawan dan khamir, oleh karena itu perlu dilakukan identifikasi cendawan dan khamir pada kelelawar yang hidup di sekitar kota Tangerang Selatan. 


\section{Metoda Penelitian}

\section{Penetapan Lokasi Sampling}

Lokasi sampling dilakukan di beberapa kecamatan di Tangerang Selatan. Teknik sampling dilakukan secara acak. Pengambilan sampel kelelawar dilakukan 2 kali yaitu pada pukul 23.00 WIB dan pukul 05.00 WIB. Pemasangan jaring kabut (Mist Net) dilakukan setiap pukul 17.00 WIB. Kelelawar yang terperangkap di jaring kabut (Mist Net) kemudian dilepaskan, lalu dibius pada Killing Jar.

\section{Pengambilan Sampel Cendawan dan Khamir}

Pengambilan sampel cendawan dan khamir diambil dari liurdan rambut bagian hidung kelelawar. Kemudian sampel diambil dengan menggunakan swab steril dan diinokulasi secara aseptis pada media PDA (Potato Dextrose Agar) pada cawan petri dan dilakukan pengulangan sebanyak 3 kali. Cawan petri kemudian disimpan pada suhu ruang selama 5-7 hari.

\section{Pengamatan Morfologi dan Identifikasi Cendawan}

Koloni cendawan yang tumbuh dilakukan pemurnian pada media PDA yang baru. Identifikasi dilakukan dengan mengamati karakter secara makroskopis dan mikroskopis. Identifikasi berdasarkan Gandjar et al. (1999); Domsch \& Gams (1980); Barnett \& Hunter (1998) dan Kurtzman \& Fell (1998).

\section{Hasil}

\section{Distribusi Jenis Cendawan dan Khamir pada Kelelawar}

Hasil dari pengamatan dari 2 bagian tubuh kelelawar yaitu rambut bagian hidung dan sampel liur pada mulut didapatkan beberapa jenis cendawan dan khamir. Data sampel cendawan dan khamir tersebut tertera pada tabel 1 dan 2. Hasil pada Tabel 2. diatas menunjukkan bahwa penyebaran dari jenis cendawan yang ditemukan tersebar cukup merata pada ketiga spesies kelelawar.

Tabel 1. Jenis-jenis kelelawar dan genus cendawan yang ditemukan

\begin{tabular}{|c|c|c|c|}
\hline \multirow[t]{2}{*}{ Jenis kelelawar } & \multicolumn{3}{|c|}{ Jenis Cendawan } \\
\hline & Situ Gintung & Bambu Apus & Taman Kota 1 BSD \\
\hline $\begin{array}{l}\text { Cynopterus } \\
\text { brachyotis }\end{array}$ & $\begin{array}{l}\text { Aspergillus niger, Mucor } \\
\text { sp. } \\
\text { Candida } \text { sp., } \\
\text { Rhodotorula } \text { sp., } \\
\text { A. Fumigatus, Fusarium } \\
\text { sp. }\end{array}$ & $\begin{array}{l}\text { A. niger, Mucor sp., } \\
\text { Fusarium sp., Candida } \\
\text { sp., } \\
\text { A. fumigatus }\end{array}$ & $\begin{array}{l}\text { A. niger, A fumigatus, } \\
\text { Fusarium sp., Mucor sp. }\end{array}$ \\
\hline $\begin{array}{l}\text { Macroglossus } \\
\text { sobrinus }\end{array}$ & $\begin{array}{l}\text { A. niger, Mucor sp., } \\
\text { Candida } \\
\text { Rhodotorula sp., A. } \\
\text { fumigatus } \\
\text { Fusarium sp. }\end{array}$ & $\begin{array}{l}\text { A. niger, A. fumigatus } \\
\text { Mucor sp., Candida sp. }\end{array}$ & $\begin{array}{l}\text { Mucor sp., Fusarium sp. } \\
\text { A. fumigatus }\end{array}$ \\
\hline Myotis muricola & $\begin{array}{l}\text { A. niger, Candida sp. } \\
\text { A. fumigatus, }\end{array}$ & - & - \\
\hline
\end{tabular}

\section{Deskripsi Jenis Cendawan dan Khamir yang Ditemukan}

Berdasarkan pengamatan cendawan secara makroskopik dan mikroskopik didapatkan 6 genus cendawan yang berhasil teridentifikasi, sehingga didapatkan identikasi cendawan 
pada ketiga lokasi pengamatan. Berdasarkan pengamatan cendawan secara makroskopik dan mikroskopik didapatkan 4 jenis cendawan dan 2 jenis khamir yaitu Aspergillus niger,A. fumigatus, Fusarium sp., Mucor sp., Candida sp., dan Rhodo-torula sp.

Permukaan koloni A. niger terlihat seperti beludru, berwarna hitam, warna sebalik koloni cream dengan tepi koloni tidak beraturan. Hasil pengamatan mikroskopis spesies $A$. niger yaitu vesikula berbentuk bulat hingga semi bulat. Metula berwarna hialin hingg akecoklatan. Konidia memiliki bentuk bulat hingga semi bulat berwarna kehitaman (Gambar 1, Tabel 2)

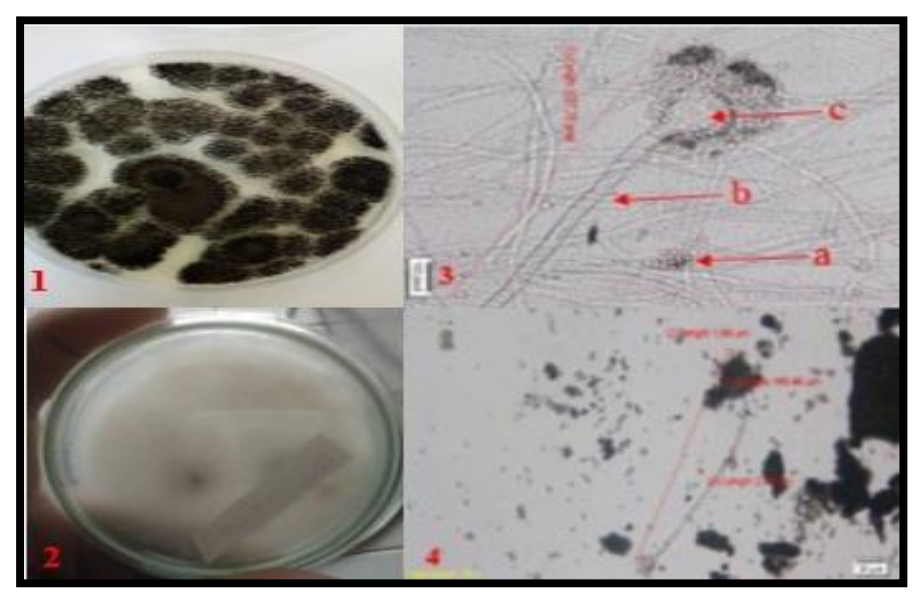

Gambar 1. Karakter morfologi Aspergillus niger. 1 Permukaan koloni pada media PDA; 2. Bagian bawah koloni; 3a. Konidia, b. Konidiofo,r c. Vesikula; 4 Konidiofor dan konidia 100x.

Koloni dari Fusarium sp. memiliki ciri makroskopis yaitu warna koloni putih kekuningan memiliki permukaan seperti kapas, menggunung dengan miselia aerial, tidak terdapat garis-garis radial dan konsentris, tidak terdapat tetes eksudat (Gambar 2). Hasil pengamatan mikroskopis ciri mikroskopis dari Fusarium sp. yaitu memiliki konidiofor yang bercabang, mikrokonidia berbentuk ovoid bersel 1, hyalin dan berdinding halus, makrokonidia berbentuk silindris terdiri dari 2-3 sel, tidak ditemui khamidiospora, hifa bersekat (Tabel 3).

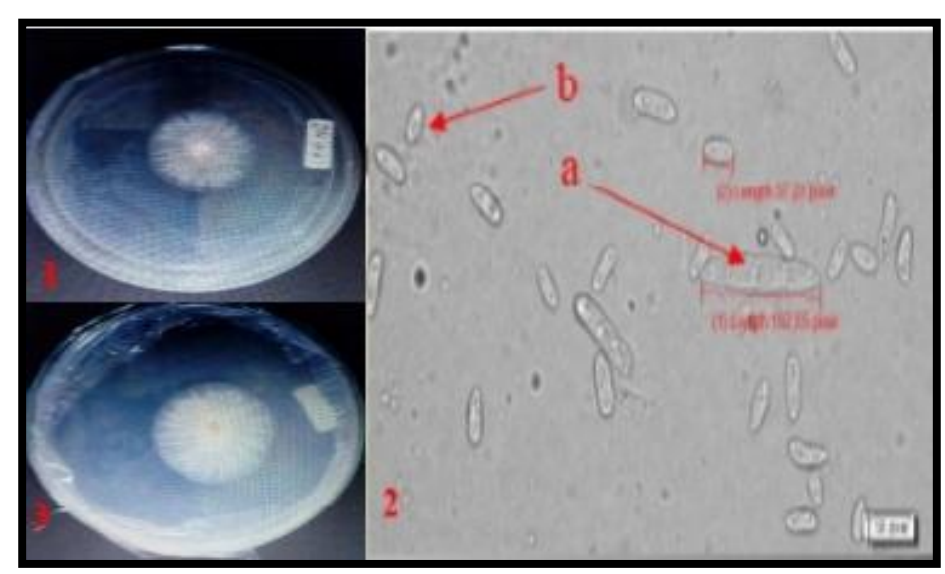

Gambar 2. Karakter morfologi Fusarium sp.1. Permukaan koloni pada media PDA; 2a. Makrokonidia, b. Mikrokonidia perbesaran 400 x; 3. Bagian bawah koloni

Berdasaarkan hasil pengamatan makroskopis, koloni Mucor sp. memiliki karakteristik yaitu warna koloni putih yang tumbuh lebat, permukaan berbentuk seperti kapas, permukaan 
koloni rata dan tidak terdapat garis-garis radial konsnetris. Ciri mikroskopis Mucor sp. terlihat hifa tidak bersekat, konidofor tunggal tidak terlihat rhizoid, sporangium berbetuk bulat, kolumela berbentuk bulat, dengan spora berbentuk bulat dan halus (Gambar 3, Tabel 2).

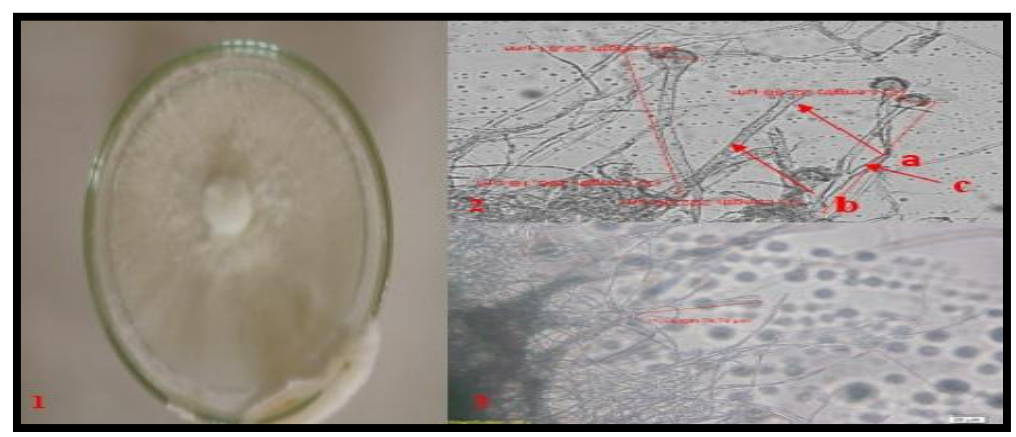

Gambar 3. Karakter morfologi dari Mucor sp. 1. Permukaan koloni pada media PDA; 2a. Sporangium, b. Sporangiofor, c.Hifa perbesaran 400x.

Koloni dari A. Fumigatus memiliki ciri makroskopis yaitu warna koloni berwarna hijau dan warna balik koloni putih, bentuk koloni bulat dengan tepi koloni rata, tekstur koloni datar dan seperti beludru. Pengamatan mikroskopis memiliki hifa bersepta, bentuk konidia bulat bahkan beberapa ada yang semi bulat serta berwarna hijau, berdinding kasar, vesikula berbentuk gada dan konidiofor tunggal (Gambar 4, Tabel 2).

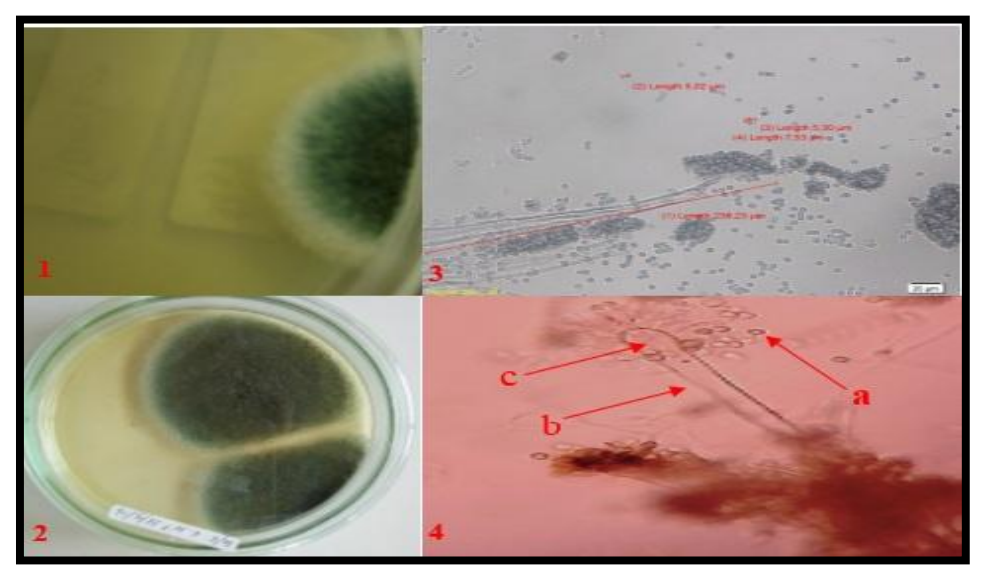

Gambar 4. Karakter morfologi dari Aspergillus fumigatus. 1,2. Kultur pada media PDA; 3. Konidiofor dan konidia, perbesaran 100x. 4a. Konidia, b. Konidiofor, c. Vesikula, perbesaran 400x.

Berdasarkan hasil pengamatan makroskopis Candida sp. berwarna putih krem mengkilap dan bentuk koloni irreguler. Hasil pengamatan mikroskopis, memiliki bentuk sel bulat hingga semi bulat, blastospora seperti membentuk rantai (pseudohifa) (Gambar 4, Tabel 3).

Hasil pengamatan makroskopis dri Rhodotula sp. spesies ini memiliki warna jingga hingga merah muda. Bentuk koloninya cenderung irreguler, permukaan koloni mengkilap, terkstur koloni agak menebal. Hasil pengamatan mikroskopis menunjukkan bahwa, memiliki sel khamir yang berbentuk semi bulat (Gambar 5, Tabel 3).

\section{Pembahasan}

Kelelawar merupakan jenis hewan yang cukup aktif dalam bergerak serta memiliki jangkauan terbang yang cukup jauh.Kelelawar buah dapat membawa makanannya dari pohon induk menuju ke sarangnya yang berjarak 100-200m (Suyanto 2001). Berdasarkan hasil sampling kelelawar diketiga lokasi penelitian, jenis kelelawar Cynopterus brachyotis dan 
Macroglossus sobrinus ditemukan jenis cendawan Aspergillus fumigatus, A.niger, Fusarium sp., Candida sp., dan Mucor sp. Sementara jenis kelelawar Myotis muricolla hanya ditemukan jenis Aspergillus niger, A. fumigatus dan Candida sp. Cendawan dan khamir tersebut ditemukan cukup banyak pada bagian rambut di sekitar hidung dan beberapa pada liur. Kelelawar yang hidupnya di dalam gua dimungkinkan terkontaminasi dengan mikroba yang hidup di dalam gua. Menurut Vanderwolf et al. (2013) bahwa di gua-gua ditemukan berbagai jenis cendawan, cendawan lendir dan khamir. Aspergillus versicolor, Aspergillus niger, Penicillium chrysogenum, Cladosporium cladosporioides, Aspergillus fumigatus, Aspergillus ustus, Aspergillus flavus, Fusarium solani, Geomyces pannorum, Trichoderma viride, Beauveria bassiana, Cephalotrichum stemonitis, Cladosporium herbarum, Alternaria alternata, Aureobasidium pullulans, Paecilomyces lilacinus, Penicillium brevicompactum, Penicillium simplicissimum, dan Rhizopus stolonifer var. Stolonifer. Man et al. (2015) memperoleh Penicillium, Aspergillus, Trichoderma dan Paelomycesdari gua di Cina. Penicillium merupakan genus yang melimpah di sedimen, bantuan dan guano kelelawar.Cendawan mudah tumbuh di lingkungan gua, karena lingkungan yang cocok dan stabil untuk pertumbuhan cendawan yaitu kelembaban yang tinggi, suhu yang rendah serta tersedia bahan organik.

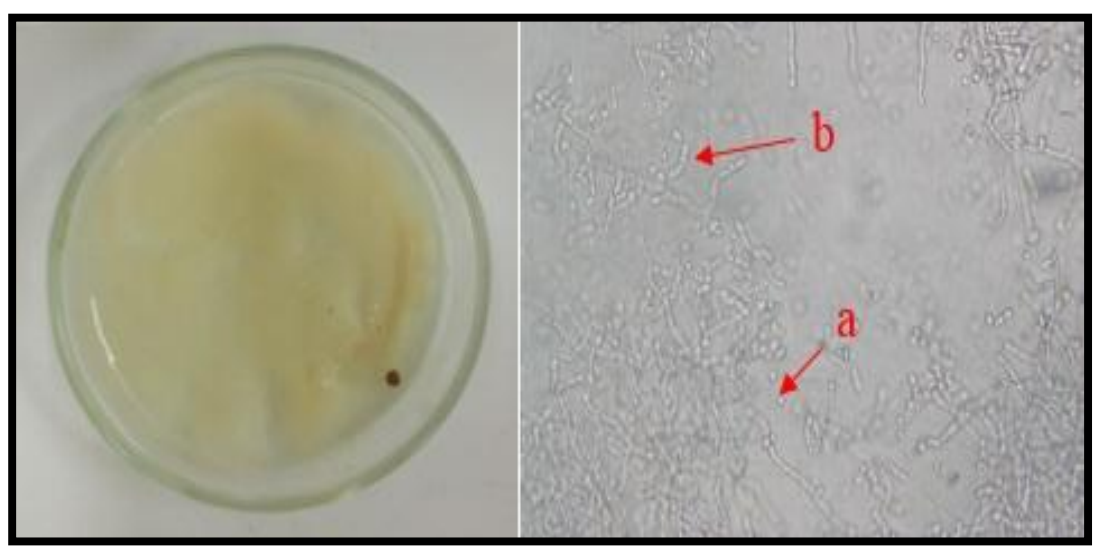

Gambar 5. Karakter morfologi dari Candida sp. 1. Kultur pada media PDA; 2 a. sel khamir, b. Blastospora, Perbesaran 400x

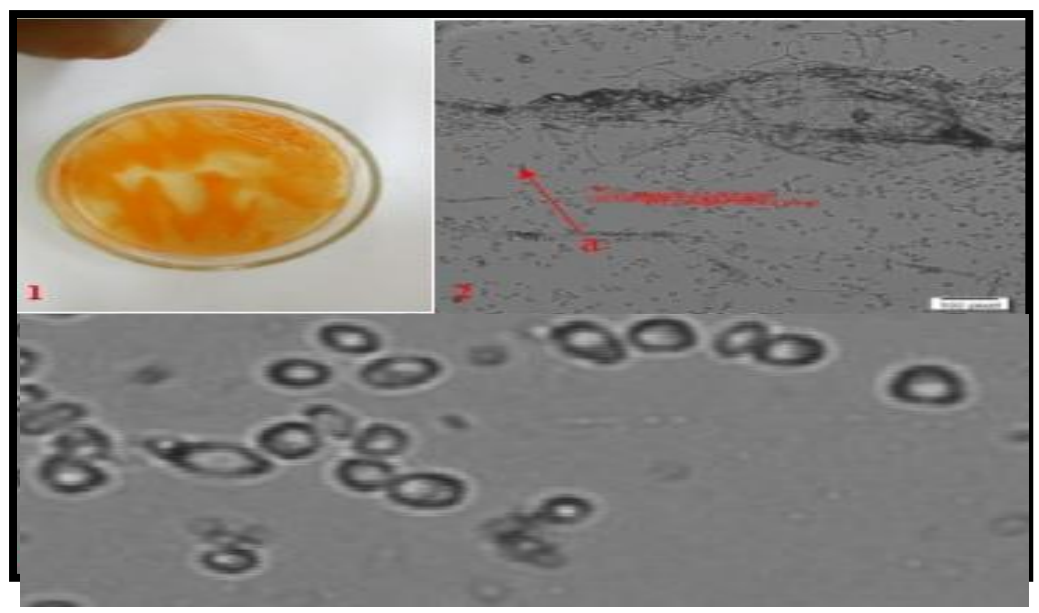

Gambar 6. Karakter morfologi dari Rhodotorula sp. 1 Kultur pada media PDA. 2 dan 3 a. Sel khamir blastospora, perbesaran 40x dan 400x. 
Fathoni dkk, 2017

Tabel 2. Karakteristik cendawan secara makroskopis dan mikroskopis

\begin{tabular}{|c|c|c|c|c|c|c|}
\hline $\begin{array}{l}\text { Karakter } \\
\text { Morfologi }\end{array}$ & A.niger & A.fumigatus & Fusarium sp. & Mucor sp. & Candida sp. & $\begin{array}{l}\text { Rhodotorula } \\
\text { sp. }\end{array}$ \\
\hline \multicolumn{7}{|l|}{ Makroskopis } \\
\hline $\begin{array}{l}\text { Bentuk koloni } \\
\text { Warna }\end{array}$ & Reguler & Reguler & $\begin{array}{l}\text { Reguler } \\
\text { Putih }\end{array}$ & Reguler & Irreguler & Ireguler \\
\hline $\begin{array}{l}\text { Permukaan } \\
\text { Warna Balik }\end{array}$ & Hitam & Hijau & kekuningan & Putih & Putih & Jingga \\
\hline koloni & Hitam & Putih & Putih & Craem & Putih & Jingga \\
\hline Tepi Koloni & Rata & Rata & Rata & Rata & - & - \\
\hline $\begin{array}{l}\text { Elevansi } \\
\text { Tekstur }\end{array}$ & Datar & Datar & Datar & Datar & Datar & $\begin{array}{c}\text { Datar } \\
\text { Licin dan }\end{array}$ \\
\hline & Beludru & Beludru & Kapas & Kapas & Licin & berlendir \\
\hline koloni & $8 \mathrm{~cm}$ & $6 \mathrm{~cm}$ & $6 \mathrm{~cm}$ & $5 \mathrm{~cm}$ & - & - \\
\hline Eksudat & - & - & - & - & - & - \\
\hline \multicolumn{7}{|l|}{ Mikroskopis } \\
\hline $\begin{array}{l}\text { Hifa } \\
\text { Bentuk }\end{array}$ & Bersepta & Bersepta & $\begin{array}{c}\text { Bersepta } \\
\text { Mikrokonidia: }\end{array}$ & Non septa & - & - \\
\hline $\begin{array}{l}\text { konidia/ } \\
\text { Sporangium }\end{array}$ & Bulat & Bulat & $\begin{array}{l}\text { oval } \\
\text { Makrokonidia: } \\
\text { lonjong }\end{array}$ & Bulat & $\begin{array}{l}\text { Blastopsora } \\
\text { semi bulat }\end{array}$ & $\begin{array}{l}\text { Blastospora } \\
\text { semi bulat }\end{array}$ \\
\hline $\begin{array}{l}\text { Konidiofor/ } \\
\text { Sporangiofor }\end{array}$ & Tunggal & Tunggal & Bercabang & Bercabang & - & - \\
\hline
\end{tabular}

Beberapa jenis cendawan dan khamir ditemukan pada bagian sekitar hidung dan air liur disebabkan kelelawar sebagai pemakan buah. Buah yang dikonsumsi dimungkinkan sudah terkontaminasi dengan cendawan-cendawan bersifat kosmopolit dan tersebar luas yang berasosiasi di tanah, organ tanaman dan insekta.Widiastui et al. (2015) melaporkan Colletotrichum, Pestalotia, Lasiodiplodia, Alternaria, Fusarium, dan Aspergillus ditemukan pada buah pascapanen. Banskar et al. (2016) melakukan penelitian mengenai kebiasaan makan kelelawar, mikroorganisme yang ditemukan pada tubuh kelelawar dimungkinkan karena mikroorganisme tersebut berasosiasi dengan makanan yang menjadi pakan kelelawar. A. niger merupakan jenis yang dapat diisolasi dari berbagai substrat diantaranya adalah buah, biji dan serasah.

Jenis Aspergillus niger dan A. fumigatus merupakan jenis yang sering ditemui pada setiap kelelewar pada penelitian ini. Genus tersebut ternyata ditemukan oleh Novakova et al. (2012) di sedimen gua. Jenis baru Aspergillus thesauricus sp. Nov. diisolasi dari berbagai substrat, termasuk bahan organik yang membusuk, udara gua dan sedimen gua Cueva del dan Tesoro, sedang Aspergillus baeticus sp. Nov. diisolasi dari endapan gua di Gua Gruta de las Maravillas. Aspergillus merupakan jenis yang kosmopolit dan mudah diisolasi serta banyak tumbuh di berbagai habitat termasuk kelelawar. A. niger adalah jenis yang banyak ditemui di daerah tropis, subtropis danmudah diisolasi dari tanah, air, buah-buahan serta serasah (Gandjar et al. 1999). Aspergillus terdistribusi secara luas dan umumnya dapat diisolasi dari tanah, serasah, debu, makanan dan udara dalam ruangan (Samson et al. 2011). Selain hal 
tersebut dimungkinkan pula tempat bersarang dari kelelawar mendukung pertumbuhan dari genus A.niger tersebut.

Fusarium sp. juga berhasil ditemukan pada bagian rambut sekitar hidung dan liur. Fusarium sp. merupakan cendawan yang sangat umum dikenal sebagai organisme penyebab penyakit pada tanaman. Fusarium sp. pada kelelawar di lokasi penelitian dimungkinkan karena kelelawar melakukan kontak fisik dengan tanaman yang terdapat Fusarium sp. sehingga genus ini melekat pada tubuhnya. Selain itu faktor kelembapan udara yang berkisar antara 65-85\% di ketiga tempat penelitian (data tidak dilampirkan) dapat mendukung pertumbuhan genus tersebut. Fusarium sp. dapat tumbuh pada kelembapan udara hingga $84 \%$ (Rahayu, 2015).

Mucor sp. ditemukan pada pada rambut dan liur dari jenis kelelawar Cynopterus brachyotis dan Macroglossus sobrinus. Genus tersebut merupakan cendawan yang banyakmenyerang tumbuhan tingkat tinggi (parasit) dan bersifat cukup kosmopolit di alam (Rahayu, 2015). Cendawan yang ditemukan pada bagian rambut bagian hidung dan liur kelelawar dimungkinkan menyebar dari lingkungan tempat mereka hidup, berasal dari makanan, atau karena kontak antara satu kelelawar dan kelelawar lainnya. Menurut Saphiro et al. (2015) berbagai jenis cendawan yang berhasil diisolasi dari tubuh kelelawar menyebar dari sumber yang spesifik dimana kelelawar melakukan kontak fisik dengannya. Jenis-jenis cendawan yang mengkolonisasi secara luas pada tubuh kelelawar berasal dari lingkungan seperti permukaan tanah dan debu pada pohon, gua, dan sumber-sumber lainnya.

Sumber penyebaran cendawan pada tubuh kelelawar dimungkinkan karena faktor makanan dan peran kelelawar sebagai polinator. Beberapa spesies mikroba dapat tumbuh pada buah dan bunga bernektar. Hal tersebut tentunya dapat mempengaruhi interkasi dari spesies polinator seperti burung dan kelelawar (Belisle et al, 2014). Komposisi cendawan yang ditemukan pada spesies polinator seperti burung dan kelelawar nectarivorous dipengaruhi oleh faktor penyebaran tanaman dan fenologi dari bunga (Belisle et al, 2014). Selain itu, keragaman cendawan yang ditemukan pada kelawar dapat dipengaruhi keragaman cendawan di gua. Kelelawar dapat mengangkut spora, di endapanguano dan bangkainya. Kelelawar mungkin sebagai vektor untukspora cendawan yang masuk dan keluar dari lingkungan gua. Sedimen merupakan tempat yang banyak (43\%) diperoleh cendawan di gua. Cendawan yangdiperoleh dapat bersifat saprofit selulolitik, saprofit karetinolitik, saprofit kitinolitik, mycoparasit, dan entoparasit (Vanderwolf et al, 2013).

Pada penelitian ini didapat Candida sp. yang memiliki potensi penyakit pada manusia dan hewan. Candida sp.dikenal sebagai jenis dimorfik yang secara normal ada pada saluran pencernaan, saluran pernafasan bagian atas danmukosa genital pada mamalia (Brown et al, 2005). Beberapa jenis cendawan yang ditemui memiliki beberapa dampak negatif yaitu berpotensi menyebabkan gangguan kesehatan, karena penyebaran sporanya dapat menyebabkan penyakit pada lingkungan hidup manusia dan kelelawarnya sendiri. Salah satu gejala kesehatan yang ditimbulkan adalah Aspergillosis atau Brooder Pneumonia. Rute utama dari infeksi Aspergillus adalah melalui inhalasi udara. Konidia dari genus ini terdeposit pada bronkioli atau alveolus (Kurzai, 2013). Geomyces destructans merupakan salah satu jenis cendawan yang menyebabkan White Nose Sydrome (WHS), bahkan dapat menyebabkan kematian pada kelelawar (Lynnaun et al. 2011; Lorch et al. 2011; Lynnaun et al. 2013).

Peranan kelelawar sebagai polinator yaitu memungkinkan berpindah dari satu lokasi ke lokasi lain, tentunya dapat meningkatkan potensi penyebaran spora cendawan dan khamir yang berasosiasi pada tubuhnya. Selain itu perlu diteliti bagaimana mekanisme penyebaran spora cendawan dan khamir untuk meminimalisir potensi penyakit yang dapat disebarkan oleh kelelawar.Meningkatnya populasi manusia serta hilangnya habitat dari kelelawar 
merupakan beberapa faktor yang mendukung penyebaran gejala penyakit yang dapat disebabkan oleh kelelawar. Hilangnya habitat berpotensi menyebabkan kelelawar masuk ke lingkungan manusia. Peranan kelelawar sebagai inang dari beberapa mikroorganisme (bakteri, cendawan dan virus) dapat meningkatkan penyebaran penyakit dari mikroorganisme tersebut. Pengaturan mengenai habitat kelelawar dan manajemen lingkungan perkotaan berperan penting untuk meminimalisir penyebaran penyakit oleh kelelawar.

Hasil isolasi dan identifikasi dari kelelawar (Ordo Chiroptera) di tiga lokasi terdapat 6 jenis cendawan yaitu spesies Aspergillus niger, A. fumigatus, Fusarium sp., Mucor sp.,serta 2 jenis khamir yaitu Candida sp., dan Rhodotorula sp.. Cendawan dan khamir yang ditemukan memiliki potensi patogen dan sumber penyebarannya dimungkinkan berasal dari buah yang menjadi pakan kelelawar, pohon, udara serta substrat lainnya dimana kelelawar melakukan kontak.

\section{Pustaka}

Baker SE. 2006. Aspergillus niger Genomics:Past, Present, and Into the Future: Medical Mycology 44:517-521.

Barnett HL, Hunter BB. 2006. Illustrated Genera of Imperfect Fungi. Ed ke-4. Minnesota (USA): APS

Belisle M, Mendehall CD, Brenes FO, Fukami T. 2014. TemporalV ariation in Fungal Communities Associated with Tropical Humming birds and Nectarivorous Bats. Fungal Ecology. Department of Biology, Stanford University, USA.

Banskar S, Devendra TM, Yogesh SS. 2016. Bacterial Diversity Indicates Dietary Overlap Among Bats of Different Feeding Habits. Journal of Microbial Research, 182: 99-108.

Brown MR, Thompson CA, Mohamed FM. 2005. Systemic Candidiasis in an Apparently Immunocompetent Dog. Journal of Veterinary Diagnostic Investigation 17(3): 272276.

Domsch KH, Gams W, Anderson TH. 1980. Compendium of soil fungi. Academic Press, London. 860 hal.

Gandjar I, Samson RA,Vanden K, Oetari A,Santoso I. 1999. Pengenalan Kapang Tropik Umum. Yayasan Obor Indonesia. Jakarta.

Hussein AA, Mohamed MAA, Moharram AM, Abdul-Kader HA, Oraby NHM. 2011. Epidemiological studies on zoonotic deep mycoses between animals and man in Assiut Governorate, Egypt.

IACUC (Institutional Animal Care and Use Committee). 2008. Orientation \& Training Fo rAnimal Users in Teaching and Research. U.S.

Kurtzman JW, Fell. 1998. The Yeats A-Taxonomy Study. 4 th Edition. Elsevier

Kurzai O. 2013. Human Fungal Pathogens 2nd Edition. Springer. Heidelberg, New York, Dordrecht, London

Lindner DL, Gargas A, Lorch JM, Banik MT, Glaeser J, Kunz TH, Blehert DS. 2011. DNAbased detection of the fungal pathogen Geomyces destructans in soils from bat hibernacula. Mycologia 103 (2): 241- 246. http://dx.doi.org/10.3852/10-262

Lorch JM, Meteyer CU, Behr MJ, Boyles JG, Cryan PM, Hicks AC, Ballmann AE, Coleman JTH, Redell DN, Reeder DM, Blehert DS. 2011 - Experimental infection of bats with Geomyces destructans causes white-nose syndrome. Nature 480 (7377): 376-378. http://dx.doi.org/10.1038/nature10590

Lynnaun JAN, Johnson, Miller AN, McCleery RA, Mc Clanahan R, Joseph A. Kath JA, Lueschow S, Porras-Alfaroa A. 2013. Psychrophilic and Psychrotolerant Fungi on Bats and the Presence of Geomyces spp. on Bat Wings Prior to the Arrival of White Nose 
Syndrome . Applied and Environmental Microbiology 79(18): 5465-5471.

Man B,Wang H, Xiang X,Wang R, Yun Y, Gong L. 2015. Phylogenetic diversity of culturable fungi in the Heshang Cave, central China. Frontiers in Microbiology 6: $1158-1169$

Novakova A, Hubka V, Saiz-Jimenez S, \& Kolarik. M. 2012. Aspergillus baeticus sp. nov. and Aspergillus thesauricus sp. nov., two species in section Usti from Spanish caves. International Journal of Systematic and Evolutionary Microbiology 62: 2778-2785 DOI 10.1099/ijs.0.041004-0

Omatsu T, Watanabe S, Akashi H, Yoshikawa Y. 2007. Biological characters of batsin relation to natural reservoir of emerging viruses. CIMID 30: 357-374.

Prasetyo PN, Noerfahmy S, Tata HL. 2011. Jenis-jenis Kelelawar Agroforest Sumatera. Bogor : World Agroforestry Centre - ICRAF, SEARegional Office.

Rahayu LA. 2015. Identifikasi dan Deskripsi Fungi Penyebab Penyakit Pada Tanaman Kacang Panjang (Vigna sinensis L.). Skripsi. Universitas Islam Negeri Syarif Hidayatullah Jakarta, Jakarta.

Saphiro JT, Thiago MR, Clarice RC, Emília D, Marcelo OB. 2015. Characterization of Fungi Associated with The Nasal Hairs of Molossid. Journal of Fungal Ecology 30: 1-4.

Samson RA, Varga J, Meijer M \& Frisvad J C. 2011. New taxa in Aspergillus section Usti. Stud Mycol 69, 81-97.

Suryaman GH. 2015. Mikosis Sistemik Pada Kelelawar Buah: Gambaran Histopatologi Organ Interna. Skripsi.I nstitut Pertanian Bogor, Bogor.

Suyanto A. 2001. Kelelawar di Indonesia. Bogor: Pusat Penelitian dan Pengembangan Biologi. LIPI.

Suyanto A, Yoneda M, Maryanto I., Maharadatun K, Sugardjito J.1998. Cheklist of the mammals of Indonesia. LIPI-JICA. Bogor.

Vanderwolf KJ, Malloch D, Mc Alpine D, Forbes GJ. 2013. A world review of fungi, yeasts, and slime molds in caves. International Journal of Speleology 42(1):77-96.

Vanderwolf KJ, Mc Alpine DF, Malloch D, Forbes GJ. 2013. Ectomycota Associated with Hibernating Bats in Eastern Canadian Caves prior to the Emergence of White-Nose Syndrome. Northeastern Naturalist 20(1): 115-130 doi: 10.1656/045.020.0109

Widiastuti A, Ningtyas HO, Priyatmojo A. 2015. Identifikasi Cendawan Penyebab Penyakit Pascapanen pada Beberapa Buah di Yogyakarta. Fitopatologi 11(3): 91-96.

Yin XJ, Wang HM, Racey P, Zhang SY. 2011. Microanatomy of the fishing batskin. Pakistan J. Zool. 43,387-392.

ZahnA, Hager I. 2005. A cave dwelling colony of Myotis daubentonii in Bavaria, Germani. J. Mam. Biol 70: 242-165. 